\title{
Erratum to: Humor at Work in Teams, Leadership, Negotiations, Learning and Health
}

Tabea Scheel and Christine Gockel

\section{Erratum to:}

T. Scheel and C. Gockel, Humor at Work in Teams, Leadership, Negotiations, Learning and Health, SpringerBriefs in Psychology, http://doi.org/10.1007/978-3-319-65691-5

In the original version of the book, chapter author names have to be included in respective chapter opening page and Laura Vetter as contributing author for Chapter 4 . The erratum book has been updated with the changes.

The updated online version of this book can be found at http://doi.org/10.1007/978-3-319-65691-5 